\title{
Prospects for Bioethanol Production from Macroalgae
}

\author{
Junying Chen ${ }^{1,2}$, Jing Bai ${ }^{1,2}$, Hongliang $\mathrm{Li}^{1,2}{ }^{*}$, Chun Chang ${ }^{1,2}$, Shuqi Fang ${ }^{1,2}$ \\ 1: School of Chemical Engineering and Energy, Zhengzhou University, China; \\ 2: Engineering Laboratory of Henan Province for Biorefinery Technology and Equipment, Zhengzhou, \\ China
}

Received September 19, 2015; Accepted October 10, 2015; Published October 11, 2015

\begin{abstract}
Macroalgae (mainly marine macroalgae, i.e. seaweeds) are considered as a very promising source for bioethanol production, because they have high carbohydrate contents, superior productivity, and wide adaptability. Macroalgae are generally grouped into three major categories: red, green, and brown algae. Each category has thousands of species, and each species possesses its unique cellular structure, biochemistry, and constitutes. Converting macroalgae to bioethanol involves pretreatment, saccharification, fermentation, and distillation; and the establishment of economic pretreatment methods is always the first key step for bioethanol production. In present, dilute-acid or alkali hydrolysis is typically used to treat macroalgal biomass. Macroalgae can be depolymerized under mild conditions as they have low lignin content. The resulting polysaccharides can be converted to ethanol through enzymatic hydrolysis, followed by adding bacteria, such as Saccharomyces cerevisiae and recombinant Escherichia coli KO11. Compared with the separate hydrolysis and fermentation process, the simultaneous saccharification and fermentation process often provided higher ethanol titer and conversion efficiency. However, the research on bioethanol production from macroalgae is still in its early stage due to both technical and economic barriers, significant amount of research and development work is needed prior to the commercialization of bioethanol manufacture from macroalgae.
\end{abstract}

Keywords: Macroalgae; Bioethanol; Marine Macroalgae; Seaweeds; Pretreatment; Hydrolysis; Saccharification; Fermentation

\section{Introduction}

Bioethanol is a clean, safe, and bio-based energy, which is commonly regarded as one of the primary candidates to replace a fraction of liquid fossil fuels [1]. The importance of using bioethanol as a vehicle fuel is increasing domestic energy production, decreasing greenhouse gas emissions, and preventing environmental pollutions [2]. The global bioethanol production rose rapidly in recent years. Table 1 shows the production of bioethanol in different countries from year 2004 to 2014. The first generation bioethanol is mainly produced from sugars and starch-rich materials. The United States and Brazil are leaders in bioethanol production, making bioethanol from corn and sugarcane, respectively. In Europe and China, mainly cereals and sugars are used as the feedstock. As the development of fuels from biomass continues apace, the consumption of edible crops and sugars has raised food security, morality, and ethics issues [3]. 
Table 1 Bioethanol production in different countries from 2004 to 2014 (million

\begin{tabular}{|c|c|c|c|c|c|c|c|c|c|c|c|c|}
\hline Country & $\begin{array}{l}\text { Major } \\
\text { feedstock }\end{array}$ & 2004 & 2005 & 2006 & 2007 & 2008 & 2009 & 2010 & 2011 & 2012 & 2013 & 2014 \\
\hline Argentina & sugarcane & 174 & 157 & 205 & 225 & 315 & 416 & 442 & 455 & 469 & 483 & 498 \\
\hline Australia & sugarcane & - & 27 & 63 & 100 & 156 & 238 & 384 & 387 & 389 & 392 & 395 \\
\hline Brazil & sugarcane & 15,208 & 15,807 & 17,932 & 22,446 & 27,674 & 25,804 & 28,960 & 31,392 & 34,299 & 37,396 & 40,625 \\
\hline Canada & cereal & 396 & 406 & 545 & 839 & 1083 & 1131 & 1573 & 1703 & 1714 & 1730 & 1721 \\
\hline China & $\begin{array}{l}\text { cereal/sugarcane/ } \\
\text { cassava }\end{array}$ & 3673 & 3438 & 3509 & 3679 & 3964 & 4109 & 4368 & 4649 & 4824 & 4962 & 5121 \\
\hline EU-27 & cereal/sugar beet & 2576 & 2940 & 3701 & 3887 & 5021 & 5762 & 6465 & 7539 & 9155 & 10,79 & 11,774 \\
\hline India & sugarcane/wheat & 1178 & 1120 & 1664 & 2082 & 2085 & 1680 & 1704 & 2430 & 2482 & 2532 & 2575 \\
\hline Indonesia & cassava & 163 & 177 & 176 & 196 & 208 & 240 & 425 & 441 & 462 & 485 & 510 \\
\hline Japan & cereal & - & 113 & 113 & 110 & 110 & 100 & 130 & 130 & 130 & 130 & 130 \\
\hline $\begin{array}{l}\text { United } \\
\text { State }\end{array}$ & corn & 12,596 & 15,332 & 20,171 & 28,929 & 35,191 & 40,544 & 46,024 & 49,114 & 51,322 & 54,058 & 57,200 \\
\hline
\end{tabular}

In order to overcome these issues, the second generation bioethanol, refined from lignocellulosic biomass, is developed to meet economic growth and morality requirements $[4,5]$. However, the cultivation of terrestrial plants requires the resources that could be used for food production. In addition, due to the structural complexity of lignocellulosic biomass, the current conversion technologies including pretreatment, saccharification, fermentation, and separation of final products are relatively costly and low-yield [6]. Among all technical barriers, the delignification is often considered as the major obstacle, which must be combated before the commercialization of lignocellulosic bioethanol can become reality [7].

Recently, algae are viewed as the source of third-generation biofuels [8]. Generally, algae are grouped into microalgae and macroalgae, based on their morphology and size. This paper reviews the development of bioethanol production from marine macroalgae, since the production of freshwater macroalgae is not significant [9]. The words of macroalgae, marine macroalgae, and seaweed are used interchangeably within the context of this article. The major advantages offered by marine macroalgae over terrestrial plants are: (1) no competing with conventional agricultural plants for land, and utilization of different water sources (seawater, brackish water, and wastewater), (2) high area productivity, (3) non-dependence on agricultural input (fertilizer, pesticides, etc.), (4) being hydrolyzed easily into glucose as they contain lower lignin content in the cell wall $[10,11]$, and (5) easier harvesting as their plant-like characteristics [12]. All of those features enable macroalgae to become a very promising biofuel feedstock for the future.

\section{Macroalgae Availability and Chemical Composition}

Macroalgae, namely seaweeds, are conventionally classified into three major groups based on their photosynthetic pigments: red algae (Rhodophyta), green algae (Chlorophyta), and brown algae (Phaeophyta) [13]. The green algae can grow in all types of water environments. While red algae grow mainly in intertropical zones, and brown algae especially grow in tempered to cold or very cold waters [14]. Macroalgae can be mass-cultivated based on current farming technologies. Up-to-date, brown and red macroalgae are cultivated more than green species. The production of brown algae alone reached 15.8 million wet tons in 2010, which were harvested from both wild habitats and coastal farms [15]. At present macroalgae are grown for food production, fertilizers, and hydrocolloid extraction in Asia (mainly in China, Korea, Philippines, and Japan) 
accounting for about $72 \%$ of global annual production [16]. The macroalgae productivity ranged from 150 to $600 \mathrm{t} / \mathrm{ha} \cdot \mathrm{y}$ fresh weight [14], and the total worldwide production attains 19 million tonnes dry matter in 2014 [17]. The amount of the mass-cultivated macroalgae is six orders of magnitude greater than that of lignocellulosic biomass [18]. That implies that macroalgae could supply sufficient feedstocks for bioethanol production.

Macroalgae are significantly different from terrestrial plants in terms of their chemical compositions. Macroalgae have agar, carrageenan, laminarin, mannitoal, mannan, ulvan, fucoidin, and alginate, which are not available in lignocellulosic biomass $[13,18]$. A summary of macroalgal divisions, compositions of their cell walls, and most significant characteristics is given in Table 2.

Table 2 Three macroalgae divisions and significant characteristics (modified from [19])

\begin{tabular}{|c|c|c|c|}
\hline & Red algae & Green algae & Brown algae \\
\hline Species & 6000 & 4500 & 2000 \\
\hline Pigments & $\begin{array}{l}\text { Chlorophyll } a \text { ( } d \text { in some } \\
\text { Florideophyceae); } \\
\text { R- and C-phycocyanin; } \\
\text { R- and B-phycoerythrin; } \\
\text { allophycocyanin; } \\
\alpha \text { - and } \beta \text {-carotene and } \\
\text { several xanthophylls }\end{array}$ & $\begin{array}{l}\text { Chlorophyll } a, b ; \alpha-, \beta \text { - and } \\
\gamma \text {-carotenes and several } \\
\text { xanthophylls }\end{array}$ & $\begin{array}{l}\text { Chlorophyll } a, c ; \beta \text {-carotene } \\
\text { and fucoxanthin and several } \\
\text { other xanthophylls }\end{array}$ \\
\hline Storage product & $\begin{array}{l}\text { Floridean starch } \\
\text { (amylopectin-like) }\end{array}$ & $\begin{array}{l}\text { Starch } \\
\text { (amylose and amylopectin) }\end{array}$ & $\begin{array}{l}\text { Laminaran } \\
\text { ( } \beta \text {-1,3-glucopyranoside); } \\
\text { Mannitol }\end{array}$ \\
\hline Cell wall & $\begin{array}{l}\text { Cellulose, xylans, several } \\
\text { sulfated polysaccharides } \\
\text { (galactans), alginate in } \\
\text { corallinaceae }\end{array}$ & $\begin{array}{l}\text { Cellulose }(\beta-1,4- \\
\text { glucopyroside), } \\
\text { Hydroxyproline glucosides; } \\
\text { xylans and mannans }\end{array}$ & $\begin{array}{l}\text { Cellulose, alginic acid, and } \\
\text { sulfated mucopolysaccharides } \\
\text { (fucoidan) }\end{array}$ \\
\hline Representative & Gracilaria spp. & Ulva fasciata & Laminaria spp. \\
\hline Carbohydrate (\%wt) & 76.7 & 43 & 60 \\
\hline Protein (\%wt) & 16.0 & 14.4 & 12 \\
\hline Lipid (\%wt) & 1.2 & 1.8 & 2 \\
\hline Ash (\%wt) & 6.1 & 16 & 26 \\
\hline Source & {$[20]$} & {$[10]$} & {$[21]$} \\
\hline
\end{tabular}

The pigment in red macroalgae is R-phycoerythrin, and their cell walls contain a small quantity of cellulose. Because the great majority of their components is gelatinous or amorphous sulfated galactan polymers, such as carageenan (up to $75 \%$ dry wt.), agar (up to 52\%), and funoran, red macroalgae are also called as carrageenophytes and agarophytes [22]. Another distinctive feature for red algae is accumulating floridean starch and floridoside, which are similar to starch. But green and brown algae do not have these carbohydrates [23, 24].

The major photosynthetic product of green macroalgae is starch, and the cell walls of their outer and inner layers are predominantly cellulose and pectin, respectively. Ulva spp. and Enteromorpha spp. have 38-52\% (dry wt.) of water-soluble ulvan and insoluble cellulose in the cell walls. Ulvan, the unique carbohydrates of green algae, is composed mainly of D-xylose, D-glucuronic acid, L-rhamnose, and sulfate [18].

Brown macroalgal cell walls are composed of cellulose, alginic acid, and other polysaccharides [19]. The accumulation product of this group are the carbohydrates of laminarin and mannitol [20]. Laminarin (i.e., $\beta$-1,3-glucans) is a unique polysaccharide present in brown seaweeds [21]. Alginate accounts for up to $40 \%$ dry wt. as a principal material of the cell wall [14], and is composed of three different uronic acids: guluronic 
acid blocks, mannuronic acid blocks, and alternative blocks of mannuronic and guluronic units.

Macroalgae biomass is easier to be converted into simple sugars than land-plant biomass due to lack of lignin. Besides cellulose and hemicellulose, many algal species accumulate high content of starch as their food material. Carbohydrate contents of macroalgae vary widely by species and cultivar, representing 30-70\%, 25-40\%, and 30$50 \%$ of dry wt. for red, green, and brown algae, respectively [4, 18, 25]. Macroalgae species with high carbohydrate contents include: Sargassum, Gracilaria, Euglena gracilis, Prymnesium parvum, Gelidium amansii [26], and Laminaria [27]. Further species selection is still needed to develop strains with higher carbohydrate contents for use as the promising candidates for bioethanol production.

\section{Bioethanol Conversion Processes from Macroalgae}

In general, the steps for bioethanol production from biomass include pretreatment, enzymatic hydrolysis, fermentation, and distillation. Almost all kinds of macroalgae can be converted to bioethanol by decomposing their polysaccharides into simple sugars, followed by fermentation with suitable bacteria. However, the development of macroalgal conversion technology is still at an early stage, and the researches were conducted mainly on lab-scale.

Figure 1 shows the flow diagram of bioethanol conversion processes from macroalgae. Unlike the terrestrial biomass, macroalgae contain contaminants from the growth environment and unique chemicals, thus there are some differences in the bioethanol technological processes from other feedstock. The fresh algal biomass collected from the cultivation site need to be processed prior to bioethanol conversion steps [28]. The biomass can be washed with tap water to remove adhering salt, sand, epiphytes, and then sun-dried. Dry seaweed is more easily transported and stored. The granular dried seaweeds can be cooked with hot water and alkali or acid to extract the polysaccharides, or be directly extracted by using supercritical fluids. The extract may be purified and separated through filtration or centrifugation. Since macroalgae have various carbohydrates such as starch, cellulose, carrageenan, laminarin, mannitol, and agar, the saccharification of them is different from that of lignocellulosic biomass [13]. The hydrolysis of macroalgae commonly conducted by using dilute sulfuric acid and enzymes. And then bacteria, such as Saccharomyces cerevisiae (NCIM 3455 and ATCC 24858) and recombinant Escherichia coli KO11 (ATCC 55124), were added to the algae hydrolysates for ethanol fermentation. There are two methods for fermentation: one is the separate hydrolysis and fermentation process (SHF), and the other is the simultaneous saccharification and fermentation process (SSF). Bioethanol distillation in the lab is often carried out by using vacuum evaporation or small-scale distillation columns. 


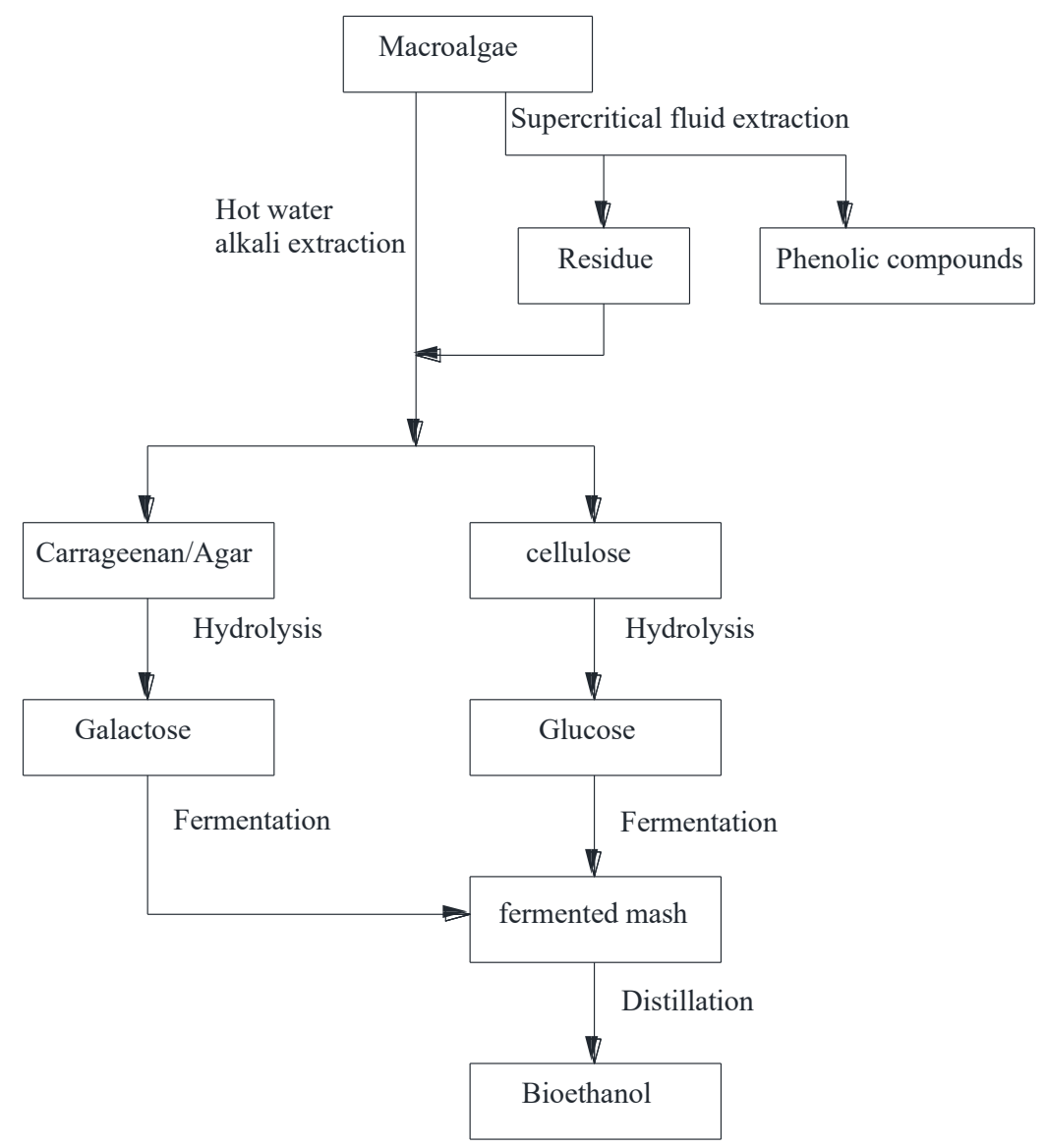

Figure 1. Block flow diagram of bioethanol conversion processes for macroalgae

\section{Overview of Pretreatment Technologies for Macroalgae}

The establishment of economic pretreatment methods is always the first key step for bioethanol production. The carbohydrate compositions of marine macroalgae highly depend on their species, which largely differ from those of terrestrial plants, so new efficient pretreatment methods are required to make the sugar monomers available for fermentation. Nowadays, although some physical, chemical, and biological pretreatments of macroalgae have been studied to increase the saccharification efficiency, those research activities looking for economically efficient technological solutions are in the early phase.

Different examples of bioethanol production and pretreatment technologies for macroalgae have been described in Table 3. Dilute-acid and alkali hydrolysis are typical physicochemical methods to treat raw macroalgal biomass [29, 30]. 
Table 3 Comparison of bioethanol yield from various seaweed feedstocks (Modified from [11]).

\begin{tabular}{|c|c|c|c|c|c|c|}
\hline Algae & feedstock & Pretreatment & $\begin{array}{c}\text { Sugar released } \\
\text { (g/g biomass) }\end{array}$ & $\begin{array}{l}\text { Ethanol yield } \\
\text { (g/g sugar) }\end{array}$ & $\begin{array}{l}\text { Ethanol } \\
(\mathrm{g} / \mathrm{L})\end{array}$ & Reference \\
\hline E. cottonii & $\begin{array}{l}\text { Residue after agar } \\
\text { extraction }\end{array}$ & Solid acid + enzyme & 0.814 & - & 14.1 & {$[31]$} \\
\hline Kappaphycus alverzii & Whole thallus & Acid & - & 0.369 & 6.8 & {$[32]$} \\
\hline Kappaphycus alverzii & $\begin{array}{l}\text { Whole biomass plus } \\
\text { carrageenan granule }\end{array}$ & Acid & 0.306 & 0.39 & 20.6 & {$[30]$} \\
\hline Gelidium amansii & Whole thallus & Acid+ enzyme & 0.566 & - & - & {$[23]$} \\
\hline Gelidium amansii & Whole thallus & Dilute acid & 0.422 & 0.38 & 27.6 & {$[33]$} \\
\hline Gelidium amansii & Whole thallus & autoclave + enzyme & 0.227 & - & 25.7 & [34] \\
\hline Gracilaria Salicornia & $\begin{array}{l}\text { Two stage hydrolysis of } \\
\text { fresh biomass }\end{array}$ & Acid + enzyme & 0.166 & 0.079 & - & [35] \\
\hline Gracilaria spp. & Whole thallus & $\begin{array}{l}\text { Sequential acid }+ \\
\text { Enzyme }\end{array}$ & 0.592 & 0.48 & 4.93 & {$[20]$} \\
\hline Gracilaria verrucosa & Pulp after agar extraction & Enzyme & $\begin{array}{l}0.87 \mathrm{~g} / \mathrm{g} \\
\text { cellulose }\end{array}$ & 0.43 & - & {$[11]$} \\
\hline Laminaria japonica & Whole thallus & Acid+ enzyme & 0.376 & 0.41 & $23-29$ & {$[23]$} \\
\hline $\begin{array}{l}\text { Sargassum } \\
\text { sagamianum }\end{array}$ & Whole thallus & Thermal liquefaction & - & 0.386 & $1-2$ & {$[36]$} \\
\hline Sargassum fulvellum & Whole thallus & Acid+ enzyme & 0.096 & - & - & {$[23]$} \\
\hline Saccharina japonica & Whole thallus & Enzyme & 0.614 & 0.41 & 37.8 & [37] \\
\hline Saccharina japonica & Whole thallus & Thermal acid & 0.456 & 0.169 & 7.7 & {$[38]$} \\
\hline Ulva lactuca & Whole thallus & Acid+ enzyme & 0.194 & - & - & [23] \\
\hline Ulva fasciata & Whole thallus & Hot buffer+ enzyme & 0.205 & 0.45 & - & {$[10]$} \\
\hline Ulva fasciata & Whole thallus & Enzymatic & 0.112 & 0.47 & - & [39] \\
\hline Zostera marina & $\begin{array}{l}\text { Supercritical } \mathrm{CO}_{2} \\
\text { extraction residue }\end{array}$ & $\begin{array}{l}\text { Sulfuric acid + } \\
\text { Enzyme }\end{array}$ & 0.582 & - & 6.55 & {$[40]$} \\
\hline
\end{tabular}

\section{Ethanol Production from Marine Macroalgae}

\subsection{Red Macroalgae}

Gelidium amansii, one of the most abundantly available red seaweed species, are known for high carbohydrate content. G. amansii predominantly consists of fibrin (cellulose) and agar (galactan) whose basic monomers are glucose and galactose, respectively [41]. The main products from dilute-acid hydrolysis of G. amansii are Dgalactose, 3,6-anhydro-L-galactose (3,6-AHG), and D-glucose [42]. The galactose and glucose are classified as fermentable simple sugars, and the 3,6-AHG is non-fermentable. Since the physical morphology of agar is softer than that of cellulose, the hydrolyzed products of galactose and 3,6-AHG are released firstly under mild hydrolysis conditions. However, the 3,6-AHG, is also known as so acid-labile that it is very apt to be decomposed into 5-(Hydroxymethyl)furfural and, subsequently, into organic acids such as formic acid and levulinic acid, which act as inhibitors in the fermentation process [43].

It is well known that the fermentable sugar yields and the amount of inhibitors primarily depends on the three major factors: acid concentration, reaction temperature, and reaction time (or residence time for continuous process)[44]. A facile continuous method for dilute-acid hydrolysis of Gelidium amansii was developed to compare with the batch operation. The continuous acid pretreatment was done at a flow rate of $40 \mathrm{~L} / \mathrm{h}$, $15 \%(\mathrm{w} / \mathrm{w})$ seaweed slurry containing $2 \%(\mathrm{w} / \mathrm{w})$ of sulfuric acid at $150^{\circ} \mathrm{C}$, and autogenerated pressure range of 3.0-3.5 bar. The product mixtures were continuously collected and the unreacted solid residual fibers were subsequently separated, followed by neutralization of hydrolysates by adding limestone $\left(\mathrm{CaCO}_{3}\right)$. The hydrolysate of $G$. amansii was then fermented by Brettanomyces custersii KCTC 18154P. Results showed the hydrolysate obtained from the continuous process attained a high sugar concentration with low quantity of inhibitors, thereby leading to the higher ethanol yield (the final 
ethanol titer of $27.6 \mathrm{~g} / \mathrm{L}$ after $39 \mathrm{~h})$, than that of the batch reactor $(11.8 \mathrm{~g} / \mathrm{L}$ after $56 \mathrm{~h})$ [33].

In order to produce a high quality hydrolysate with minimal inhibitors, sequential acid and enzyme hydrolysis of Gracilaria spp. was studied. The dilute-sulfuric acid hydrolysis process was carried out by using $2 \%(\mathrm{w} / \mathrm{v})$ of dried Gracilaria spp., and optimized at $121{ }^{\circ} \mathrm{C}$ via varying acid concentrations $(0.025-0.25 \mathrm{~mol} / \mathrm{L})$ and residence time (up to $60 \mathrm{~min}$ ). The hydrolysates were adjusted to various $\mathrm{pHs}(\mathrm{pH} \mathrm{2-8)}$ ) at the end of the acid treatment. After $\mathrm{pH}$ adjustment, the enzymatic hydrolysis was performed with various amounts of cellulase $(0.01-8 \% \mathrm{w} / \mathrm{v})$ at $50^{\circ} \mathrm{C}$ for $6 \mathrm{~h}$. The Gracilaria hydrolysate was fermented in batch and repeated batch modes by using immobilized $S$. cerevisiae $\mathrm{Wu}-2$ cells. The process maximally released $11.85 \mathrm{~g} / \mathrm{L}$ of glucose and galactose, yielding $4.72 \mathrm{~g} / \mathrm{L}$ of ethanol at the rate of $0.48 \mathrm{~g} / \mathrm{g}$ sugar-consumed with a $94 \%$ conversion efficiency [20].

For converting red macroalga Gelidium amansii (GA), GA was autoclaved at $121^{\circ} \mathrm{C}$ for $60 \mathrm{~min}$ to reduce the galactan content. After the autoclave treatment, $177 \mathrm{~g}$ glucose and $50 \mathrm{~g}$ galactose were produced from $1 \mathrm{~kg}$ GA. Enzymatic hydrolysis was conducted with a cocktail of cellulase (Celluclast ${ }^{\circledR} 1.5 \mathrm{~L}$ ) and $\beta$-glucosidase (Novozyme 188). SHF ( $2 \%$ substrate loading, w/v) produced a maximum ethanol concentration of $3.33 \mathrm{~g} / \mathrm{L}$ and an ethanol conversion yield of $74.7 \%$ after $6 \mathrm{~h}$. In contrast, SSF achieved an ethanol concentration of $3.78 \mathrm{~g} / \mathrm{L}$ and an ethanol conversion yield of $84.9 \%$ after $12 \mathrm{~h}$. With an increased biomass concentration, the ethanol concentration of $25.7 \mathrm{~g} / \mathrm{L}$ was attained from $15 \%(\mathrm{w} / \mathrm{v})$ treated biomass after $24 \mathrm{~h} \mathrm{SSF}$ processing [34]. The results indicated that autoclaving can increase the sugar yields and ethanol conversion yield of GA, and also showed that SSF is superior to SHF for ethanol production.

Carrageenan is the major polysaccharide constituent of red algae, which consists of repeating of $\beta(1-3)$-D-galactose and $\alpha(1-4)-3,6$-anhydro-D-galactose [41]. Purified carrageenan is generally used for forming thick solution or gel [22]. During manufacturing carrageenan, seaweeds were treated with alkali solution $(1-10 \% \mathrm{NaOH}$ or $\mathrm{KOH}$ ) at $80^{\circ} \mathrm{C}$ for $0.5-5 \mathrm{~h}$, resulting in $60-70 \%$ solid residues (SWBC) with high carbohydrates content. One study used this stream of seaweed wastes as the bioethanol feedstock [45]. Researchers treated seaweed wastes with peracetic acid (PAA) followed by different types of ionic liquids (ILs): 1-ethyl-3-methylimidazole acetate ([Emim][OAc]), 1-hexylpyridinium chloride ([Hpy][Cl]), and 1-ethyl-3methylimidazolium diethylphosphate ([Emim][DEP]). For a 48-hour saccharification, the cellulose conversions of untreated and pretreated seaweed wastes with PAA followed by [Emim][OAc], [Hpy][Cl], and [Emim][DEP] were 77, 62, 91, and 84\%, respectively. The untreated SWBC had a high cellulose conversion, which may be caused by the alkali pretreatment or low lignin and hemicellulose contents of this seaweed. Meanwhile, PAAIL pretreatments did produce more amorphous cellulose structures, which are beneficial to cellulose conversion [46].

\subsection{Green Macroalgae}

The most common green macroalga, Ulva prolifera (UP), contains about $62 \%$ carbohydrates, $27 \%$ protein, $0.3 \%$ lipid, and $11 \%$ ash of dry matter [47]. However, the carbohydrates of $U$. prolifera are chiefly in the form of complex hydrocolloid ulvan, which shows very high viscosity by undergoing a random coil to double helix transition while cooling [48]. The high viscosity of ulvan is one reason that hindered the high production of bioethanol from this species. The depolymerase produced by Catenovulum 
spp. LP, showed high efficiency and high specificity to UP for monomer sugar production. During the enzymatic hydrolysis, the viscosity of $1.2 \%$ UP solution obviously declined from initially 1127 to $7.2 \mathrm{mPa} \cdot \mathrm{s}$ within $95 \mathrm{~min}$. Reducing sugar yield attained $50.2 \%$ in $6 \mathrm{~h}$ at the optimal conditions of $\mathrm{pH} 6.0$ and $35^{\circ} \mathrm{C}$ [49]. Compared to the commercial enzymes, this depolymerase might bring promising prospects for bioethanol production from $U$. prolifera biomass.

Chaetomorpha linum, one of green macroalgae species, has rigid epidermal cell walls consisting of highly crystalline cellulose [35]. The cellulose content (35-40\%) of $C$. linum is higher than that of other algae, and similar to that of land-based biomass. For breaking down the cellulosic structure of $C$. linum, following five pretreatment methods have been employed: steam explosion (STEX), hydrothermal pretreatment (HTT), plasma-assisted pretreatment (PAP), wet oxidation (WO), and ball milling (BM) [50]. HTT and WO were performed with $4 \%$ C. linum at $200^{\circ} \mathrm{C} ;$ C. linum $(35 \%)$ was treated by STEX at $200-210^{\circ} \mathrm{C}$ for 5 min; the PAP treatment was performed with raw material (50\%) for $20-60$ min with $1 \%$ ozone gas flow rate of $0.01 \mathrm{~L} / \mathrm{s}$; and the $\mathrm{BM}$ experiment was carried out for $18 \mathrm{~h}$ at $180 \mathrm{rpm}$. WO, HTT, PAP, BM, and STEX resulted in glucan concentrations of $74,60,46,38,36 \mathrm{~g} / 100 \mathrm{~g}$ dry matter, respectively. Using a SSF process with the commercial cellulase enzymes (Celluclast $1.5 \mathrm{~L}$ and Novozyme 188) and $S$. cerevisiae ATCC 96581 for ethanol fermentation, WO and BM showed the highest ethanol yield of $77.2 \%$ of the theoretical ethanol yield. However during WO, about $50 \%$ of the biomass (especially C5 sugars) was lost. The results suggested that physical pretreatment method like BM is already effective enough to break down the cellulosic structure of $C$. linum.

\subsection{Brown Macroalgae}

Conversion of Sargassum spp., a brown seaweed species, was conducted by using dilute acid hydrolysis and SHF [51]. In terms of glucose and other reducing sugar yields, the optimal pretreatment condition was found to be $\left(3.4-4.6 \% \mathrm{w} / \mathrm{v} \mathrm{H}_{2} \mathrm{SO}_{4}, 115^{\circ} \mathrm{C}\right.$ and 1.50 h). The residue after pretreatment was hydrolyzed with cellulase (Trichoderma reeseii ATCC 26921) and $\beta$-glucosidase, and then fermented by $S$. cerevisiae for $48 \mathrm{~h}$. The ethanol conversion rate achieved $89 \%$, which was obviously higher than the theoretical yield of $51 \%$ based on glucose as substrate. Since all glucose was consumed during fermentation, other sugar sources might be present in the hydrolysate.

Zostera marina is a source of natural antioxidants in the food and pharmaceutical industries. After washing, drying, grinding, and sieving, antioxidants (phenolic compounds) were extracted by using supercritical $\mathrm{CO}_{2}$ from this brown alga. The contents of lignin, hemicellulose, and $\alpha$-cellulose in the residues were $22.4 \%, 16.89 \%$, and $27.39 \%$, respectively. Because supercritical fluid extraction already loosen the lignin structure [40], the raffinate phase would either be directly used for SSF or hydrolyzed by enzyme/dilute acid. Under optimized conditions, a reducing sugar yield of $58.24 \mathrm{~g} / 100 \mathrm{~g}$ dry-feed was reached by consecutive enzymatic and acid hydrolysis with a commercial cellulase (Cellic CTec2).

\section{Prospect on the Utilization of Macroalgae for Biofuels Production}

As an abundant and carbon-neutral renewable resource, macroalgae represent an unrealized feedstock that might expand existing bioethanol industries. Currently, 
macroalgae are gaining more attention because of their plant-like characteristics, fast growth rate, superior productivity, lower energy inputs, and no land requirements. In terms of availability, the annual production of brown algae was 9.72 million tons (dry weight) in 2004, representing the largest seaweed source; and red algae produced 3.99 million tons of dry biomass at the second place [52]. Another advantage of macroalgae is high content of carbohydrates (cellulose and hemicellulose) and the paucity of lignin resistant [53]. Although, the notion of macroalgae-based bioethanol production is environmentally better than the fossil fuels, but still suffer from low cost effectiveness and technological barriers [14]. The industrial-scale technologies for seaweed conversion still require significant basic research and development.

Since the price of a final product is directly related to the cost of feedstock, the price of seaweed is an important factor in the economics of a bioethanol process. The estimated macroalgal bioethanol production cost is ca. $\$ 0.50 / \mathrm{kg}$ ( $\mathrm{dw}$ ) ( $\$ 0.16$ from corn) [54]. Algae production cost is connected with the available technologies for cultivation, harvesting, and processing. Although macroalgae can be cultivated both naturally and artificially, approximately $90 \%$ of total feedstock were currently harvested from cultivated sources [21]. The production cost will decrease with the increase of macroalgae yield per unit area. To date, there are limited numbers of economic assessments on seaweed-based bioethanol technologies, as the research just started. Although it is impossible to make full-scale and periodically life cycle assessment right now, the processing technologies for bioethanol production from macroalgae should be estimated not only from the viewpoints of technical feasibility and economic efficiency, but also from the environmentally friendly point and the recycling of byproducts.

\section{ACKNOWLEDGMENTS}

The authors are thankful for the financial support from the Major program for Science and Technology Development of Henan Province, China (No. 132102310042), and the crosswise project of Henan Tianguan Biofuel Eng. Co. Ltd., China. (No. 211500532704).

\section{CONFLICTS OF INTEREST}

The authors declare that there is no conflict of interests regarding the publication of this paper.

\section{REFERENCES}

[1] Morales, M., Quintero, J., Conejeros, R., and Aroca, G. (2015). Life cycle assessment of lignocellulosic bioethanol: Environmental impacts and energy balance. Renewable and Sustainable Energy Reviews, 42, 1349-1361. DOI: 10.1016/j.rser.2014.10.097

[2] Bayrakci, A. G., and Koçar, G. (2014). Second-generation bioethanol production from water hyacinth and duckweed in Izmir: A case study. Renewable and Sustainable Energy Reviews, 30, 306-316. DOI: 10.1016/j.rser.2013.10.011

[3] Gupta, A., and Verma, J. P. (2015). Sustainable bio-ethanol production from agroresidues: A review. Renewable and Sustainable Energy Reviews, 41, 550-567. DOI: $10.1016 /$ j.rser.2014.08.032

[4] Goh, C. S., and Lee, K. T. (2010). A visionary and conceptual macroalgae-based third-generation bioethanol (TGB) biorefinery in Sabah, Malaysia as an underlay 
for renewable and sustainable development. Renewable and Sustainable Energy Reviews, 14(2), 842-848. DOI: 10.1016/j.rser.2009.10.001

[5] Chovau, S., Degrauwe, D., and Van der Bruggen, B. (2013). Critical analysis of techno-economic estimates for the production cost of lignocellulosic bio-ethanol. Renewable and Sustainable Energy Reviews, 26, 307-321. DOI: 10.1016/j.rser.2013.05.064

[6] Balat, M., Balat, H., and Öz, C. (2008). Progress in bioethanol processing. Progress in Energy and Combustion Science, 34(5), 551-573. DOI: 10.1016/j.pecs.2007.11.001

[7] Tan, I. S., and Lee, K. T. (2014). Enzymatic hydrolysis and fermentation of seaweed solid wastes for bioethanol production: An optimization study. Energy, 78, 53-62. DOI: 10.1016/j.energy.2014.04.080

[8] John, R. P., Anisha, G. S., Nampoothiri, K. M., and Pandey, A. (2011). Micro and macroalgal biomass: A renewable source for bioethanol. Bioresource Technology, 102(1), 186-193. DOI: 10.1016/j.biortech.2010.06.139

[9] Lawton, R. J., de Nys, R., and Paul, N. A. (2013). Selecting Reliable and Robust Freshwater Macroalgae for Biomass Applications. PLoS ONE, 8(5), e64168. DOI: 10.1371/journal.pone.0064168

[10] Trivedi, N., Gupta, V., Reddy, C. R. K., and Jha, B. (2013). Enzymatic hydrolysis and production of bioethanol from common macrophytic green alga Ulva fasciata Delile. Bioresource Technology, 150, 106-112. DOI:

10.1016/j.biortech.2013.09.103

[11] Kumar, S., Gupta, R., Kumar, G., Sahoo, D., and Kuhad, R. C. (2013). Bioethanol production from Gracilaria verrucosa, a red alga, in a biorefinery approach.

Bioresource Technology, 135, 150-156. DOI: 10.1016/j.biortech.2012.10.120

[12] Maceiras, R., Rodrı'guez, M., Cancela, A., Urréjola, S., and Sánchez, A. (2011). Macroalgae: Raw material for biodiesel production. Applied Energy, 88(10), 3318-3323. DOI: 10.1016/j.apenergy.2010.11.027

[13] Borines, M. G., de Leon, R. L., and McHenry, M. P. (2011). Bioethanol production from farming non-food macroalgae in Pacific island nations: Chemical constituents, bioethanol yields, and prospective species in the Philippines. Renewable and Sustainable Energy Reviews, 15(9), 4432-4435. DOI: 10.1016/j.rser.2011.07.109

[14] Chen, H., Zhou, D., Luo, G., Zhang, S., and Chen, J. (2015). Macroalgae for biofuels production: Progress and perspectives. Renewable and Sustainable Energy Reviews, 47, 427-437. DOI: 10.1016/j.rser.2015.03.086

[15] FAO (2012a). 2010 Fishery and Aquaculture Statistics. ftp://ftp.fao.org/FI/CDrom/CD_yearbook_2010/index.htm. (Accessed on 9/11/2015)

[16] Roesijadi, G., Jones, S.B., Snowden-Swan, L. J., Zhu, Y. (2010). Macroalgae as a Biomass Feedstock: A Preliminary Analysis. Pacific Northwest National Laboratory-19944.

[17] Redmond, S., Green, L., Yarish, C., Kim, J., and Neefus, C. (2014). New England Seaweed Culture Handbook-Nursery Systems.

http://seagrant.uconn.edu/publications/aquaculture/handbook.pdf. (Accessed on 9/11/2015) 
[18] Jung, K. A., Lim, S.-R., Kim, Y., and Park, J. M. (2013). Potentials of macroalgae as feedstocks for biorefinery. Bioresource Technology, 135, 182-190. DOI: 10.1016/j.biortech.2012.10.025

[19] Davis, T. A., Volesky, B., and Mucci, A. (2003). A review of the biochemistry of heavy metal biosorption by brown algae. Water Research, 37(18), 4311-4330. DOI: $10.1016 / \mathrm{S} 0043-1354(03) 00293-8$

[20] Wu, F.-C., Wu, J.-Y., Liao, Y.-J., Wang, M.-Y., and Shih, I.-L. (2014). Sequential acid and enzymatic hydrolysis in situ and bioethanol production from Gracilaria biomass. Bioresource Technology, 156, 123-131. DOI: 10.1016/j.biortech.2014.01.024

[21] Fasahati, P., Woo, H. C., and Liu, J. J. (2015). Industrial-scale bioethanol production from brown algae: Effects of pretreatment processes on plant economics. Applied Energy, 139, 175-187. DOI: 10.1016/j.apenergy.2014.11.032

[22] Lobban, C. S., Wynne, M.J. ( 1981). The Biology of seaweeds. Blackwell Scientific Publications.

[23] Kim, N.-J., Li, H., Jung, K., Chang, H. N., and Lee, P. C. (2011). Ethanol production from marine algal hydrolysates using Escherichia coli KO11. Bioresource Technology, 102(16), 7466-7469. DOI: 10.1016/j.biortech.2011.04.071

[24] Bucholc, K., Szymczak-Żyła, M., Lubecki, L., Zamojska, A., Hapter, P., Tjernström, E., and Kowalewska, G. (2014). Nutrient content in macrophyta collected from southern Baltic Sea beaches in relation to eutrophication and biogas production. Science of The Total Environment, 473-474, 298-307. DOI: 10.1016/j.scitotenv.2013.12.044

[25] Hou, X., Hansen, J. H., and Bjerre, A.-B. (2015). Integrated bioethanol and protein production from brown seaweed Laminaria digitata. Bioresource Technology, 197, 310-317. DOI: 10.1016/j.biortech.2015.08.091

[26] Wi, S. G., Kim, H. J., Mahadevan, S. A., Yang, D.-J., and Bae, H.-J. (2009). The potential value of the seaweed Ceylon moss (Gelidium amansii) as an alternative bioenergy resource. Bioresource Technology, 100(24), 6658-6660. DOI: 10.1016/j.biortech.2009.07.017

[27] Adams, J., Gallagher, J., and Donnison, I. (2009). Fermentation study on Saccharina latissima for bioethanol production considering variable pretreatments. Journal of Applied Phycology, 21(5), 569-574. DOI: 10.1007/s10811008-9384-7

[28] Bharathiraja, B., Chakravarthy, M., Ranjith Kumar, R., Yogendran, D., Yuvaraj, D., Jayamuthunagai, J., Praveen Kumar, R., and Palani, S. (2015). Aquatic biomass (algae) as a future feed stock for bio-refineries: A review on cultivation, processing and products. Renewable and Sustainable Energy Reviews, 47, 634653. DOI: $10.1016 /$ j.rser.2015.03.047

[29] Lin, L.-h., Tako, M., and Hongo, F. (2000). Isolation and Characterization of ICarrageenan from Eucheuma serra (Togekirinsai). Journal of Applied Glycoscience, 47(3-4), 303-310. DOI: 10.5458/jag.47.303

[30] Khambhaty, Y., Mody, K., Gandhi, M. R., Thampy, S., Maiti, P., Brahmbhatt, H., Eswaran, K., and Ghosh, P. K. (2012). Kappaphycus alvarezii as a source of bioethanol. Bioresource Technology, 103(1), 180-185. DOI:

10.1016/j.biortech.2011.10.015 
[31] Tan, I. S., and Lee, K. T. Comparison of different process strategies for bioethanol production from Eucheuma cottonii: An economic study. Bioresource Technology. DOI: 10.1016/j.biortech.2015.08.008

[32] Meinita, M. D. N., Hong, Y.-K., and Jeong, G.-T. (2012). Detoxification of acidic catalyzed hydrolysate of Kappaphycus alvarezii (cottonii). Bioprocess and Biosystems Engineering, 35(1-2), 93-98.

[33] Park, J.-H., Hong, J.-Y., Jang, H. C., Oh, S. G., Kim, S.-H., Yoon, J.-J., and Kim, Y. J. (2012). Use of Gelidium amansii as a promising resource for bioethanol: A practical approach for continuous dilute-acid hydrolysis and fermentation.

Bioresource Technology, 108, 83-88. DOI: 10.1016/j.biortech.2011.12.065

[34] Kim, H. M., Wi, S. G., Jung, S., Song, Y., and Bae, H.-J. (2015). Efficient approach for bioethanol production from red seaweed Gelidium amansii. Bioresource Technology, 175, 128-134. DOI: 10.1016/j.biortech.2014.10.050

[35] Wang, X., Liu, X., and Wang, G. (2011). Two-stage Hydrolysis of Invasive Algal Feedstock for Ethanol FermentationF. Journal of Integrative Plant Biology, 53(3), 246-252. DOI: 10.1111/j.1744-7909.2010.01024.x

[36] Lee, H. Y., Jung, K. H., and Yeon, J. H. (2011). Repeated-batch operation of surface-aerated fermentor for bioethanol production from the hydrolysate of seaweed Sargassum sagamianum. Journal of microbiology and biotechnology, 21(3), 323-331.

[37] Wargacki, A. J., Leonard, E., Win, M. N., Regitsky, D. D., Santos, C. N. S., Kim, P. B., Cooper, S. R., Raisner, R. M., Herman, A., and Sivitz, A. B. (2012). An engineered microbial platform for direct biofuel production from brown macroalgae. Science, 335(6066), 308-313. DOI: 10.1126/science.1214547

[38] Jang, J.-S., Cho, Y., Jeong, G.-T., and Kim, S.-K. (2012). Optimization of saccharification and ethanol production by simultaneous saccharification and fermentation (SSF) from seaweed, Saccharina japonica. Bioprocess and Biosystems Engineering, 35(1-2), 11-18. DOI: 10.1007/s00449-011-0611-2

[39] Trivedi, N., Reddy, C. R. K., Radulovich, R., and Jha, B. (2015). Solid state fermentation (SSF)-derived cellulase for saccharification of the green seaweed Ulva for bioethanol production. Algal Research, 9, 48-54. DOI:

10.1016/j.algal.2015.02.025

[40] Pilavtepe, M., Sargin, S., Celiktas, M. S., and Yesil-Celiktas, O. (2012). An integrated process for conversion of Zostera marina residues to bioethanol. The Journal of Supercritical Fluids, 68, 117-122. DOI: 10.1016/j.supflu.2012.04.019

[41] Jol, C. N., Neiss, T. G., Penninkhof, B., Rudolph, B., and De Ruiter, G. A. (1999). A Novel High-Performance Anion-Exchange Chromatographic Method for the Analysis of Carrageenans and Agars Containing 3,6-Anhydrogalactose. Analytical Biochemistry, 268(2), 213-222. DOI: 10.1006/abio.1998.3059

[42] Kim, C., Ryu, H. J., Kim, S. H., Yoon, J.-J., Kim, H. S., and Kim, Y. J. (2010). Acidity tunable ionic liquids as catalysts for conversion of agar into mixed sugars. Bull Korean Chem Soc, 31(2), 511-514.

[43] Quemener, B., and Lahaye, M. (1998). Comparative analysis of sulfated galactans from red algae by reductive hydrolysis and mild methanolysis coupled to two different HPLC techniques. Journal of Applied Phycology, 10(1), 75-81.

[44] Zhang, B., Wang, L., Shahbazi, A., Diallo, O., and Whitmore, A. (2011). Dilutesulfuric acid pretreatment of cattails for cellulose conversion. Bioresource Technology, 102(19), 9308-9312. DOI: 10.1016/j.biortech.2011.07.008 
[45] Azevedo, G., Hilliou, L., Bernardo, G., Sousa-Pinto, I., Adams, R. W., Nilsson, M., and Villanueva, R. D. (2013). Tailoring kappa/iota-hybrid carrageenan from Mastocarpus stellatus with desired gel quality through pre-extraction alkali treatment. Food Hydrocolloids, 31(1), 94-102.

[46] Uju, Wijayanta, A. T., Goto, M., and Kamiya, N. (2015). Great potency of seaweed waste biomass from the carrageenan industry for bioethanol production by peracetic acid-ionic liquid pretreatment. Biomass and Bioenergy, 81, 63-69. DOI: 10.1016/j.biombioe.2015.05.023

[47] Ortiz, J., Romero, N., Robert, P., Araya, J., Lopez-Hernández, J., Bozzo, C., Navarrete, E., Osorio, A., and Rios, A. (2006). Dietary fiber, amino acid, fatty acid and tocopherol contents of the edible seaweeds Ulva lactuca and Durvillaea antarctica. Food Chemistry, 99(1), 98-104. DOI: 10.1016/j.foodchem.2005.07.027

[48] Kirchmajer, D. M., Steinhoff, B., Warren, H., Clark, R., and in het Panhuis, M. (2014). Enhanced gelation properties of purified gellan gum. Carbohydrate Research, 388, 125-129. DOI: 10.1016/j.carres.2014.02.018

[49] Li, Y., Huang, Z., Qiao, L., Gao, Y., Guan, H., Hwang, H., Aker, W. G., and Wang, P. (2015). Purification and characterization of a novel enzyme produced by Catenovulum sp. LP and its application in the pre-treatment to Ulva prolifera for bio-ethanol production. Process Biochemistry, 50(5), 799-806. DOI: 10.1016/j.procbio.2015.02.013

[50] Schultz-Jensen, N., Thygesen, A., Leipold, F., Thomsen, S. T., Roslander, C., Lilholt, H., and Bjerre, A. B. (2013). Pretreatment of the macroalgae Chaetomorpha linum for the production of bioethanol-Comparison of five pretreatment technologies. Bioresource Technology, 140, 36-42.

[51] Borines, M. G., de Leon, R. L., and Cuello, J. L. (2013). Bioethanol production from the macroalgae Sargassum spp. Bioresource Technology, 138, 22-29. DOI: 10.1016/j.biortech.2013.03.108

[52] Roesijadi, G., Copping, AE, Huesemann, MH, Forster, J, Benemann, JR. (2008). Technoeconomic feasibility analysis of offshore seaweed farming for bioenergy and biobased products. Battelle Pacific Northwest Division Report.

[53] Rezania, S., Ponraj, M., Din, M. F. M., Songip, A. R., Sairan, F. M., and Chelliapan, S. (2015). The diverse applications of water hyacinth with main focus on sustainable energy and production for new era: An overview. Renewable and Sustainable Energy Reviews, 41, 943-954. DOI: 10.1016/j.rser.2014.09.006

[54] Aitken, D., Bulboa, C., Godoy-Faundez, A., Turrion-Gomez, J. L., and AntizarLadislao, B. (2014). Life cycle assessment of macroalgae cultivation and processing for biofuel production. Journal of Cleaner Production, 75, 45-56. DOI: 10.1016/j.jclepro.2014.03.080

Article copyright: (C) 2015 Junying Chen, Jing Bai, Hongliang Li, Chun Chang, and Shuqi Fang. This is an open access article distributed under the terms of the Creative Commons Attribution 4.0 International License, which permits unrestricted use and distribution provided the original author and source are credited. 